\author{
Weronika Sałek \\ Uniwersytet Jana Kochanowskiego w Kielcach \\ ORCID: 0000-0002-7766-7490
}

\title{
Situation of British women's magazines during the COVID-19 pandemic
}

\begin{abstract}
The women's magazine segment in the UK accounts for a significant part of the publishing market and has the highest readership in the country. Despite its popularity, women's press faces many problems caused by the expansion of new types of media. Media researchers and insiders report about a crisis and stagnation of this publishing branch. The COVID-19 pandemic, which began in early 2020, has compounded problems within the women's press market, but also accelerated the development of existing trends. Moreover, it has sped up the digitization of previously printed content. The COVID crisis has also taken its toll on the organization of editorial work. Under current restrictions related to COVID, magazines which previously were not as popular, have come to the fore - periodicals on cooking.
\end{abstract}

Keywords: press, press market, women's magazines, United Kingdom, COVID-19 pandemic.

\section{Sytuacja bryłyjskich magazynów kobiecych podczas pandemii COVID-19}

Streszczenie

Segment magazynów kobiecych w Wielkiej Brytanii zajmuje znaczącą część rynku uydauniczego i jest jednym z najchętniej czytanych w tym kraju. Mimo to prasa kobieca spotyka się z wieloma problemami spowodowanymi ekspansją nowych mediów. Medioznawcy i osoby związane z branżą medialną donoszą o kryzysie czy też stagnacji tego odłamu uydawniczego. Pandemia COVID-19, która rozpoczęła się u 2020 roku, nie tylko pogłębiła załamanie rynku prasy kobiecej, lecz także przyspieszyła rozwój dotychczasowych trendów. Globalna epidemia przede uszystkim uczyniła bardziej dynamiczną digitalizację treści dotychczas wydawanych u druku. Kryzys covidowy dał się we znaki również w kuestiach organizacji pracy redakcji. W czasach ograniczeń na prowadzenie wyszły nowe subsegmenty kobiece dotychczas niecieszące się dużą popularnością - periodyki traktujące o kulinariach.

Słowa kluczoue: prasa, rynek prasouy, magazyny kobiece, Wielka Brytania, pandemia COVID-19.

\section{Introduction}

The press is an exceptionally large sector of UK media, and it is dominated by the newspaper and magazine segments. Amongst the latter, the women's magazine industry deserves special attention, as it is not only the most developed area, but also 
has the highest readership. Therefore, the focus of this article is an analysis of the effects of the COVID-19 pandemic on the women's magazine market in Britain.

The outbreak of the global pandemic at the beginning of 2020 has had a huge impact on all trades, both national and international, including the media industry. Reports from media researchers and insiders suggest that the spread of coronavirus is one the most significant events to affect mass media in recent years. The relevance and severity of the issue are other indicators of the need for research into this press sector. The hypothesis of this article is that COVID-19 has had a major influence on the women's magazine industry.

This article aims to analyse every element of the women's press market in Britain: its size, structure and current state of affairs. There is very little UK research on this subject $^{1}$; that which does exist has become obsolete. In Poland, there is no recorded data $^{2}$; consequently, the information presented below is a result of personal research based on materials from British institutions such as PAMCo, ABC, and NRS; media research data platforms including Mediatel.co.uk, Campaign.co.uk and Whatsnewinpublishing.com; and recent press releases and reports from publishers regarding women's magazines in the UK. The article will also demonstrate how the women's magazine sector in Britain has been affected by COVID-19, it will highlight new challenges and attempt to determine future repercussions for the industry.

\section{Size and structure of the women's press market}

The magazine sector is of great importance to the British press industry as a whole. Magazines are very popular among consumers, which translates into sales results and consequently, considerable profits for publishers. According to the latest report from the National Readership Survey (NRS), as many as 71\% of Britons surveyed in the $15+$ age group read magazines. This is 37.2 million people $^{3}$ out of the total $52.6 \mathrm{~m}$ UK population. The size of the magazine sector is estimated at about 2,300 titles. The biggest, most complex and most popular press segment in the UK is considered to be women's magazines. The NRS reports that $23 \%$ of the population over the age of 15 $(12.2 \mathrm{~m})$ are readers of weekly magazines. As many as $41 \%$ of the population $(21.4 \mathrm{~m})$ read

\footnotetext{
1 The women's press in the UK has been researched by: A. Gough-Yates, Understanding Women's Magazines, Taylor \& Francis Ltd, London 2002; J. Hermes, Reading Women's Magazines, Wiley-Blackwell, Cambridge 1995; A. Wood, Modernism and Modernity in British Women's Magazines, Routledge, New York 2020.

2 The British media system has been researched by: J. Adamouski. See inter alia: System medialny Wielkiej Brytanii [in:] Wybrane zagraniczne systemy medialne, ed. J. Adamouski, Wydawnictua Akademickie i Profesjonalne, Warszawa 2008, pp. 45-85; Czwarty stan. Media masowe w pejzażu społecznym Wielkiej Brytanii, Oficyna Wydawnicza Aspra-JR, Warszawa 2006. Comparative research on British and Polish true story magazines conducted by: O. Dąbrouska-Cendrouska, Segment magazynów true story w Polsce i w Wielkiej Brytanii. Analiza na podstawie „Chwili dla Ciebie” i „Take a Break”, „Media i Społeczeństuo” 2020, No. 12, pp. 244-261.

3 Nrs.co.uk, http://wuw.nrs.co.uk/total-market-3/ (accessed: 3.01.2021).
} 
monthly magazines for women ${ }^{4}$. The author has not been able to establish the official data on the actual current number of women's magazine titles in circulation; therefore, these numbers are only estimates. Based on the latest data published by the Audit Bureau of Circulations (ABC) there are 79 controlled titles ${ }^{5}$. However, it is worth noting that apart from these publications, there may be others not controlled by the ABC. Available data suggests that there are over 100 titles for women in circulation on the UK magazine's market.

Women's press in the UK is generally categorised based on frequency of publication. Magazines are released weekly (known as weeklies), fortnightly, monthly (monthlies, glossy magazines or glossies), bi-monthly and quarterly. However, 'weekly' and 'monthly' are the most commonly used terms; the former encompassing magazines published both weekly and fortnightly, the latter monthly and bi-monthly. Of these categories, monthly magazines form the largest group. Over the past decade, the women's press market has seen a decrease in publishing frequency. British women's magazines are further differentiated by theme. Weekly magazines contain the following subgroups: real life (aka true story), lifestyle, celebrity gossip, and a combination of the above. Monthly magazines comprise two main groups: themed lifestyle magazines and multi-themed lifestyle magazines (general interest magazines). Typical genres of themed lifestyle magazines include fashion, house \& garden, food \& drink, parenting, family and wedding. Multi-themed publications are based on a variety of these subjects.

\section{Market situation prior to COVID-19 pandemic - trends, problems and changes}

For years, Bauer Media - a German publishing giant - has been the leading selling magazine publisher in the UK. Bauer Media retains its leadership position in the numbers sold across the entire women's press market as well as in its individual categories ${ }^{6}$.

Prior to the pandemic, the magazine titles with the largest circulation where those given away for free. According to data from $2019^{7}$, the biggest title that year was 'Tesco Magazine' with a free circulation of $1.9 \mathrm{~m}$ copies $^{8}$. The second place was taken by 'Asda Magazine' with nearly 1.8m copies, and the last place on the podium was attained by 'Waitrose \& Partners Food' with 677,000 copies. Paid publications for women were much less popular. 'Slimming World Magazine' was the leader among paid for magazines with 494,000 sold copies.

\footnotetext{
${ }^{4}$ Nrs.co.uk, http://wuw.nrs.co.uk/latest-results/facts-and-figures/magazines-factsfigs/ (accessed: 3.01.2021).

${ }^{5}$ Abc.org.uk, https://www.abc.org.uk/Certificates/49640049.pdf (accessed: 3.01.2021).

${ }^{6}$ Bauermedia.co.uk, https://www.bauermedia.co.uk/newsroom/press-releases/bauer-media-confirms-lead-as-uks-biggest-magazine-publisher-2 (accessed: 3.01.2021).

${ }^{7}$ Ch. Tobitt, Women's mags ABCs: Pick Me Up and Elle circulations fall by quarter + full figures, https://www.pressgazette.co.uk/womens-mags-abcs-pick-me-up-and-elle-circulations-fall-by-quarter-full-figures/ (accessed: 3.01.2021).

${ }^{8}$ Numbers are rounded to one decimal place.
} 
Considering sales, monthly magazines appear to be more consistent than weeklies. In 2019, almost all weekly magazines saw sales losses of about 10\% compared to the previous year. Real life magazine 'Pick Me Up' saw the largest loss - 24\% whereas the lifestyle magazine 'Woman's Weekly' recorded the smallest loss of $4 \%$. The only magazine with no losses recorded was 'The Lady' with 23,000 copies. Among subject-specific weeklies, the largest and most popular are real-life titles, e.g. its current leader 'Take a Break' (almost 416,000 copies), or second in line 'That's Life!' (173,000).

The situation of monthly magazines, however, is somewhat better. There are still considerable losses but, unlike weekly magazines, monthlies experienced some grouth compared to the previous year. Seven periodicals observed some marginal grouth and nine have not recorded any change. The worst affected magazine turned out to be 'WW Magazine' which saw its circulation plummet by 41\%. Other titles recorded losses of about several percent. Magazines with the highest circulation count are those given away for free. The magazines mentioned earlier: 'Tesco Magazine', 'ASDA Magazine' and 'Waitrose \& Partners' are leaders on the entire women's press market as well as within monthly magazine's segment. In this category, the most popular are the general interest lifestyle magazines, within which are the aforementioned free magazines and, among the others, paid 'Slimming World Magazine'.

For the past 20 years, print media in the UK (as well as other countries), has been undergoing a crisis. Women's press has not been spared either. As reported by ABC, the women's magazine market has been experiencing a sharp decline in printing volume. Consequently, there has been a drop in sales suggesting less interest amongst readers. Publishers ascribe the reason of this situation to a change in market structure which followed the development of new information technologies, accessibility of digital content and, in particular, the increase in importance of social media. Women continue to search out the content targeted towards them, however, they seem to prefer alternative distribution channels. According to the most recent readership research (Jan-Dec 2017), almost all British publishers report more digital than traditional readers ${ }^{9}$. Readers are attracted to online publications because they are free, but also because they are multimedia and easy to access. Women's magazines are increasingly being read online, which has led to a decline in print sales.

These changes in the women's press market have been followed by movement in the structure of the entire segment. First and foremost, many publishing companies have gone out of business and others have decided to re-align their publishing strategies because of underperformance or insufficient profits. Some publishers decided to explore the digital platform; trying to move their magazines online or combine print publishing with an online presence. Magazines like 'Goodbye Company' and 'InStyle' chose the first option, becoming exclusively digital. Hearst UK and Bauer, on the other hand, integrated print and digital formats of publishing. The British version of 'Cosmopolitan' is available

${ }_{9}^{9}$ WNIP, UK magazine and newspaper readership across all platforms revealed for first time, https://whatsnewinpublishing.com/uk-magazine-newspaper-readership-across-platforms-revealed-first-time/ (accessed: 3.01.2021). 
on Snapchat and Instagram, whereas 'Grazia' developed its own mobile application and reports live on Facebook. The integration of traditional and digital content is, however, relatively slow. This is due to a lack of stability in the market and consumers being torn between content offered by traditional press and by alternative sources available on various portals and social media.

Whilst analysing the effects of the press crisis, it is worth noting a new competition emerging on the market. Publishers and businesses alike have started introducing new magazine titles, including free periodicals, which turned out to be very popular. Free magazines dominate the women's press arena and, as already mentioned, reach the highest circulation figures. The most popular free periodicals like 'Tesco Magazine', 'Waitrose \& Partners Food' or 'ASDA Magazine' known as supermarket magazines, are released by retail giants for their customers and given away in their stores. Such periodicals resemble lifestyle magazines in terms of their theme or layout. In addition, they cover various topics like health, fashion, beauty, cooking, household etc., which makes them direct competition for paid alternatives. Not only are they more popular, their circulation also significantly outnumbers that of paid titles. For example, the circulation of the biggest free title - 'Tesco Magazine' (1.9m copies), is four times higher than that of the biggest title among paid-for periodicals - 'Slimming World Magazine'. This expansion of free periodicals for women is a sign of a new, growing trend on the publishing market. Consumers find free magazines very attractive. The idea that readers can find quality content, without having to pay extra for it, is very appealing. The availability of supermarket magazines has a knock-on effect on the readership of paid titles, leading to lesser gains for publishers from advertisements. The magazine categories that have been hit the worst are lifestyle and celebrity gossip, showing losses of up to $25 \%$ year-on-year. To summarize, women's press in the UK is currently facing a crisis due to competition from new media. As a result, the publishing industry has undergone radical changes aiming to adjust to this new state of affairs. The major trends of recent years are, firstly, diversification into digital publishing - either combining both paper and digital content or forgoing traditional forms of publishing in favour of digital formats; secondly, introducing free content by businesses unrelated to the publishing sector.

\section{Effect of COVID-19 pandemic on women's magazines in the UK}

The virus SARS-CoV-2, which causes acute respiratory disease, has led to the outbreak of a global COVID-19 pandemic. In the UK, the first confirmed $\operatorname{cases}^{10}$ were identified in late February 2020. Reports regarding transmission rate have confirmed concerns about the severity of the situation. Country leaders, following WHO's advice, started to make decisions to protect the public. Amongst other measures, sanitary restrictions, curfeus, and bans on mass gatherings have been introduced, followed by national

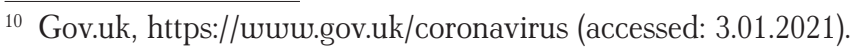




\section{Weronika Sałek}

lockdowns. Many industries, including media, have been affected by movement restrictions, bans on international travel and the closing of a majority of businesses.

The first consequences of the COVID-19 pandemic were already noticeable in March 2020. This was also the month of the biggest decisions, reactions to the current situation and forecasts within the publishing industry. Above all, publishers faced organisational problems. The movement restrictions, and later, a ban on leaving home, made it impossible for journalists to get to their places of work and this, in turn, delayed the distribution of the press. For example, the June issue of 'Delicious' magazine was delayed for so long that its publisher decided not to release it and instead delivered a double issue a month later. Other magazines like 'Elle', 'Glamour', 'Grazia' and 'Tatler'11 faced a similar situation. Publishing houses were forced to re-organize and introduced remote working - allowing editors to continue with work from their homes.

The coronavirus pandemic and strict measures that followed have intensified challenges faced by women's magazines and print in general. The ban on leaving homes caused a decline in sales and circulation because potential readers have not been purchasing copies via traditional distribution channels, i.e. newsstands, in-stores etc. It is important to point out that not all publishing houses make half-year reports public. In addition, because of the coronavirus, some publishers have made a decision to pull out of the six-month reporting period. Amongst them is publishing giant Hearst UK, the publisher of some of the biggest women's magazine titles ('Good Housekeeping', 'Cosmopolitan'), which has instead decided to publish the full-year results in February 2021. The CEO of Hearst UK, James Wildman, claims that a report reflecting a six-month period 'will not provide a robust view of true circulation figures, particularly in comparison with the same period last year (Jan-Jun 2019)'12. Coming back, however, to the aforementioned decline, almost all women's titles which did share their results for the first half of the year, saw their circulation fall in comparison with annual and last quarter figures. The largest decline for the first-half of 2020 saw celebrity magazines 'Heat' falling by 33\% and 'Closer' by $27 \%{ }^{13}$. The most recent report shows that the worst hit were weeklies with the fastest circulation decline prior to the pandemic. However, monthly magazines, although also having negative value, stayed within their norm. Despite losses no worse than before the pandemic, they were still significant for the market, and it became necessary for publishing houses to plan ahead and secure their financial resources for future months. Hearst UK admitted that losses caused by the pandemic will 'eat up a large proportion of its cash resources', which may have an impact on the profitability of some of its titles ${ }^{14}$.

\footnotetext{
${ }^{11}$ Zinio.com, https://support.zinio.com/hc/en-us/articles/360040746832-Magazines-affected-by-COVID-19 (accessed: 3.01.2021).

${ }^{12}$ Ch. Tobitt, ABCs: Gardening and cooking mags biggest lockdown winners as women's titles see circulation fall, https://www.pressgazette.co.uk/abcs-gardening-and-cooking-mags-biggest-lockdown-winners-as-womens-titles-see-circulation-fall/ (accessed: 3.01.2021).

${ }^{13}$ Ibidem.

${ }^{14}$ Ch. Tobitt, Hearst UK prepares for COVID-19 to eat 'large proportion' of cash resources after losses of £2m in 2019, https://wuw.pressgazette.co.uk/hearst-uk-prepares-for-COVID-19-to-eat-large-proportion-of-cash-resources-after-losses-of-2m-in-2019/ (accessed: 3.01.2021).
} 
Interestingly, although the majority of women's magazines saw a decline, the culinary sector recorded some profits. Insiders have confirmed that this was due to the fact that many people, having a lot of free time during lockdown, were looking for inspiration and forms of activity they could take part in at home ${ }^{15}$. The food magazine 'Olive' saw the biggest growth - 35\%; 'BBC Easy Cook' followed with 14\%. A marginal grouth can be observed in another food-related magazine - 'BBC Good Food' (1\%). Aside from food publications, grouth was also recorded by 'Take a Break Monthly' (1\%) and the free general interest title 'Tesco Magazine' (3\%). 'Time Out', in turn, has not changed its position ${ }^{16}$. Taking into account that only two out of six free women's titles released their results, of which one recorded growth and the other loss, it is not possible to clearly define the trend of free periodicals during the pandemic.

As reported by publishers, due to restricted access to magazine purchasing, interest in women's magazine subscriptions has risen. Print subscriptions have been enthusiastically purchased, as well as paid access to digital magazine content for smartphones, tablets and PCs. The CEO of Bauer Media's UK publishing business, Chris Duncan, revealed '(...) the demand for our products remained strong and even increased in some markets. We saw home delivered and digital copies grow through our subscriptions channels, and sales in independent shops rise as more of our readers sought out copies closer to home ${ }^{\prime 17}$. Publishing houses particularly appreciate digital subscriptions. According to the digital consulting company Jellyfish, in the UK, interest in magazine subscriptions rose rapidly in the first week of lockdown in March and did not slow down until June. Some publications are even reporting triple-digit surges ${ }^{18}$. Bauer have observed an increase of over 70\% in the number of new subscriptions purchased online compared to last year's figures, and Hearst reported its numbers more than doubled across the given month in $2019^{19}$. The entire women's magazine sector grew its total brand reach by $325 \%^{20}$. Taking into account all forms of subscriptions, the majority of controlled titles have seen a satisfactory growth of around 30\%. 'Tatler' has seen the highest increase of 36\% and the fashion magazine 'Vogue' was up by 35\% - both titles have upped their new subscriber acquisitions by more than a third ${ }^{21}$. Some titles, however, have seen a drop in subscriptions, e.g. fashion magazines 'Elle' and 'Harper's

\footnotetext{
${ }^{15}$ Five things you need to know from the latest PAMCo release for magazines, https://mediatel. co.uk/news/2020/09/16/five-things-you-need-to-know-from-the-latest-pamco-release-for-magazines/ (accessed: 3.01.2021).

${ }^{16}$ Ch. Tobitt, ABCs: Gardening and cooking...

17 Ibidem.

${ }^{18}$ Magazines and the pandemic - how reading become more popular than ever, https://www. storaenso.com/en/neusroom/neus/2020/6/magazines-and-the-pandemic (accessed: 3.01.2021). ${ }^{19}$ UK Magazine Subscription Surge during Pandemic, https://freeportpress.com/uk-magazine-subscriptions-surge-during-pandemic/ (accessed: 3.01.2021).

${ }^{20}$ Magazines and the pandemic...

${ }^{21}$ F. Mayhew, PAMco: Monthly mags fare better than weeklies under lockdown with some big audience gains, https://wuw.pressgazette.co.uk/pamco-monthly-mags-fare-better-than-weeklies-under-lockdoun-with-some-big-audience-gains/ (accessed: 3.01.2021).
} 
Bazaar', which fell by 26\% and 22\% respectively ${ }^{22}$. Such losses are common for this type of magazine and do not exceed the current norm.

Data shows that access to mobile and online content plays a pivotal role in the popularity of subscriptions and women's press in general. Hearst's chief executive maintains that the increase in subscriptions allowed them to hold a relatively stable position during the COVID crisis $^{23}$. The biggest gains in digital circulation were experienced by 'Heat' (50\%) and 'Closer' (28\%) which were considered great successes. However, even such strong digital grouth is unable to compensate for the losses in print revenue. Nevertheless, this is a reason for optimism amongst publishers, as it foreshadows a change in readership patterns, which in the long run, may have a positive impact on the future position of the press. The publisher of 'Yours' shares this view and admits that the title had 'massively increased its digital circulation, as even this mature audience changed its purchasing habit'. The CEO of Bauer Media also added that 'circulations remain on track for robust recovery in the second half of the year as distribution patterns settle. ${ }^{24}$ It can be said with all certainty that periodicals which existed in a digital format prior to the pandemic, have been unquestionably successful. Moreover, the increased number of online readers testifies to the impact of the lockdown on reading patterns British readers, who up until now had only been buying business and everyday press via the internet, now also take notice of magazines and increasingly access them on mobile devices ${ }^{25}$.

During lockdown, both paid-for and free magazines for women have seen a decline in advertising revenue. Due to the COVID crisis advertisers were forced to limit their spending on print magazines and instead have focused on digital media, in which content for women has been more popular. The Professional Publishers' Association, which unites publishing groups like Condé Nast UK, Hearst UK and Time Out Group, has estimated that in the second quarter of 2020 print advertising revenue will fall by anywhere between $20 \%$ and $95 \%{ }^{26}$ (the figures for this period have not yet been released, therefore, it is difficult to verify such speculations). Titles funded predominantly by advertising have experienced unprecedented difficulties, and the only option for them has been to save and limit their spending. As a result, many publishers were forced to take drastic action, such as redundancies or salary cuts for an indefinite period of time, depending on the duration of the pandemic. Due to many journalists being laid off (or furloughed), publishing houses have started to experience operational problems. Journalists who have continued working had to take over the duties of their laid off colleagues, which forced them to work longer hours and more effectively. This is yet another reason why women's periodicals were delayed in getting to their readers.

\footnotetext{
${ }^{22}$ Ibidem.

${ }^{23}$ Ch. Tobitt, Hearst UK prepares for COVID-19...

${ }^{24}$ Ch. Tobitt, ABCs: Gardening and cooking...

${ }^{25}$ Five things you need to know...

${ }^{26}$ K. Hopkins, How will Coronavirus Impact Already Fragile Glossy Magazine Print Ads?, https://wud.com/business-news/media/hou-coronavirus-impact-already-fragile-magazine-print-adverti-1203558596/ (accessed: 3.01.2021).
} 
The aforementioned complications in the industry have started a debate on print publications being heavily reliant on advertising revenue. The future of the entire press industry is being reflected upon. In an interview with WWD, US-based media analyst Jack Myers predicted that more and more magazines will completely change their business models to become less dependent on advertisers ${ }^{27}$.

Another effect of the coronavirus pandemic which followed the decline in sales was the questioning of the viability of some publishing titles. Publishers driven by concern for the long-term condition of their businesses and thus, securing future high profits, decided to withdraw, suspend or redesign their less successful titles. The biggest publisher in the UK's magazine market - Bauer - has made the decision to withdraw some of its titles. As many as 10 titles are being challenged, one of them, parenting magazine 'Mother\&Baby'28, was considered not sustainable as a print women's title and has been withdrawn from print and moved to a website - www.motherandbaby. co.uk. The Polish media researchers Wieslaw Godzic and Maciej Mysliwiec, referring to the situation in Poland, stated that the pandemic was merely an excuse to close unprofitable titles ${ }^{29}$. Mysliwiec was right to point out that magazines that are being closed during the pandemic are niche titles ${ }^{30}$. The $\mathrm{ABC}$ confirms this; their data shows that 'Mother\&Baby' had a circulation of only 9,000 $\operatorname{copies}^{31}$. It can be speculated that if it wasn't for the pandemic, Bauer would have considered closing it soon anyway. Apart from Bauer's 'Mother\&Baby', the print editions of free magazines 'Time Out' and 'Stylist' were suspended. In this way, their publishers were trying to deal with the impact the coronavirus has had on their business models and to protect their staff'. The producers of 'Time Out' very quickly made steps to adjust to the situation and changed the title to 'Time $\operatorname{In}^{33}$. The new title was a manifestation of a new theme and reference to the government's call to stay at home and help to slow down the spread of the virus. Before the re-brand, the magazine had been publishing on activities away from home, whereas now, the editorial group champions in-home entertainment avenues while continuing in its advisory style. The 'Stylist' also postponed its print publication and launched a mobile application, which is a true copy of the print

${ }_{27}$ Magazines and the pandemic...

${ }^{28}$ M. Jefferson, Bauer Media considers closure for ten magazines due to COVID-19, https:// mediatel.co.uk/news/2020/05/19/bauer-media-considers-closure-for-ten-magazines-due-to-COVID-19/ (accessed: 3.01.2021).

${ }^{29}$ N. Bochyńska, Bauer zamyka tytuły $i$ zwalnia. „Koronawirus staje się pretekstem, wymówka dla wydawców”, https://wuw.wirtualnemedia.pl/artykul/bauer-zamyka-tytuly-i-zwalnia-koronawirus-staje-sie-pretekstem-wymowka-dla-wydawcow (accessed: 3.01.2021).

30 J. Stawiany, Wydawnictwo Bauer zamyka siedem tytułów i zwalnia prawie 30 osób, https:// wuw.press.pl/tresc/61447, wydawnictwo-bauer-zamyka-siedem-tytulow-i-zwalnia-prawie-30osob (accessed: 3.01.2021).

${ }^{31}$ Ch. Tobitt, Women's mags ABCs: Pick Me Up and Elle...

${ }^{32}$ Ch. Tobitt, Coronavirus: Time Out and Stylist free magazines go digital-only as readers stay home, https://wuw.pressgazette.co.uk/coronavirus-time-out-and-stylist-free-magazines-go-digital-only-as-readers-stay-home/ (accessed: 3.01.2021).

33 D. Barnett, How Magazines Are Responding To Coronavirus, https://wwu.fashionmonitor. com/blog/nL/how-magazines-are-responding-to-coronavirus (accessed: 3.01.2021). 


\section{Weronika Sałek}

edition and is available to download for free during the lockdown from Google's Play Store and Apple's App Store ${ }^{34}$. Stylist Ltd plans to return to print production once the pandemic ends.

The pandemic and related restrictions, affecting both the publishing market and readers directly, accelerated the already existing trends within women's press in the UK, including partial or total digitalization of print publications. In the face of the crisis, some magazines which combined print and digital formats, keeping in mind the wellbeing of their readers, have temporarily made available for free their usually paid-for contents. This was the case with the May editions of 'Tatler' and British 'Vogue', which for the whole month were available to dounload for free ${ }^{35}$. Currently both magazines have returned to their original paid access. Free downloads were offered not only to make it easier for readers to access entertainment content in these difficult times, but also to counter any fake news found online, suggesting that the press is a more reliable source of information about the virus ${ }^{36}$. Publishers encouraged readers to support their favourite titles and buy print as well as online editions, arguing that press is reliable and, as opposed to the internet, provides broad and specialist knowlege based on multiple sources ${ }^{37}$. The role of the press during these uncertain times has been emphasized, and certain titles that may be the best choice during the pandemic have been suggested.

As a consequence of the pandemic, the coronavirus itself has become a new subject in women's press. Magazines increased the volume of health content reporting about protection, symptoms and risks of COVID-19. Periodicals for women have elaborated on the importance of physical and mental health during lockdoun, educating the readers at the same time. The press have backed up government restrictions and called for the following of advice and guidance on safety measures. During the pandemic, there has also been more advisory content related to home activities, which were already the domain of British women's titles. In magazines there have been many recommendations for works of high and popular culture, as well as culinary, garden and DIY advice. All of this is aimed at promoting creativity and personal development during lockdown.

${ }^{34}$ Currently the subscription costs a symbolic 0.99p.

35 D. Barnett, How Magazines Are Responding...

${ }^{36}$ E. Nascimbene, Magazine covers in Times of COVID-19, https://barcelonabridalueek.com/ magazine-covers-in-times-of-the-COVID-19/ (accessed: 3.01.2021).

${ }^{37}$ Ed., Wydawcy prasy: przetrwamy w stużbie dla czytelnika tylko dzięki czytelnikowi, https://wuw.forbes.pl/biznes/prasa-w-czasie-pandemii-koronawirusa-list-boguslawa-chraboty/ qr7rks0 (accessed: 3.01.2021). 


\section{Summary}

The COVID-19 pandemic has had a significant impact on the women's magazines market in the UK. Firstly, due to the coronavirus and related disruptions, publishers had to reconsider the organization of work and transition editorial teams to remote working. Secondly, the pandemic deepened the already long pre-existing crisis of print publishing. This is noticeable in the print circulation decline, but also in a reported drop in advertisement revenue. As a result, many publishing houses have had to limit their budgets, and thus, make difficult decisions about redundancies or closing less profitable titles (like in the case of Bauer's 'Mother\&Baby'). Therefore, the least resilient titles suffered the most. However, it appears that COVID-19 only accelerated the inevitable. Weak titles with no promising future have been eliminated allegedly because of difficulties caused by the pandemic, but the coronavirus only exposed the poor condition print publishing was in, and the fact that it was not fully prepared to withstand the crisis. The pandemic and lockdown have merely intensified the clear trends already affecting the industry. In order to facilitate access to the press for readers during lockdown, publishers have had to consider transitioning from print to digital media. Magazines focused around cooking have seen a positive after-effect of the global pandemic. Having gained a lot of interest from readers, their circulation figures increased. Moreover, magazines already existing in a digital format found themselves in a favourable position, as did magazine subscriptions, which indicates the development of new trends in consumer behaviour. Therefore, it can be assumed that the most resilient and least susceptible to crisis were magazines with strong digital backgrounds and those whose business models were based on generating their profits directly from readers and not relying on advertising revenue alone.

Despite many negative repercussions, it seems the COVID-19 pandemic has had a relatively gentle impact on the British women's press market. The losses within this sector were not greater than those of other countries. In Australia, Bauer closed many more titles with long market presence like 'Harper', 'InStyle', 'Women's Health', 'Good Health' and 'OK'; considerably reducing the choice of available titles for women. Also, hundreds of people have lost their jobs. Compared to this, the situation in the UK seems to be much more stable. Nevertheless, insiders from British publishing houses confirm that COVID-19 has had a significant impact on the market situation. It is important to note that the above observations are merely based on preliminary research. Individual market players are yet to provide profit and loss statements. The full picture will become clearer in March 2021 when annual reports are published. However, people related to the media industry (amongst others Michael Moszynski, founder and $\mathrm{CEO}$ of the London Advertising Agency) have already forecasted that the impact of the pandemic will have much more severe repercussions for the print publishing market than the financial crisis of $2008^{38}$.

${ }^{38}$ K. Hopkins, How will Coronavirus Impact... 


\section{References}

ABC Results: publisher reaction, https://www.inpublishing.co.uk/articles/abc-results-publisher-reaction-15166 (accessed: 3.01.2021).

Abc.org.uk, https://www.abc.org.uk/Certificates/49640049.pdf (accessed: 3.01.2021).

Adamouski J.W., Czwarty stan. Media masowe w pejzażu spotecznym Wielkiej Brytanii, Oficyna Wydawnicza Aspra-JR, Warszawa 2006.

Adamouski J.W., System medialny Wielkiej Brytanii [in:] Wybrane zagraniczne systemy medialne, ed. J. Adamouski, Wydawnictua Akademickie i Profesjonalne, Warszawa 2008, pp. $45-85$.

Barnett D., How Magazines Are Responding To Coronavirus, https://uww.fashionmonitor.com/ blog/nL/how-magazines-are-responding-to-coronavirus (accessed: 3.01.2021).

Bauer to close number of titles in wake of the coronavirus, https://www.betterretailing.com/ neuspapers-magazines/bauer-publishing-to-close-titles-coronavirus/ (accessed: 3.01.2021).

Bauer.co.uk, https://www.bauermedia.co.uk/role-of-mags-and-radio-during-c19 (accessed: 3.01.2021).

Bauermedia.co.uk, https:/wuw.bauermedia.co.uk/newsroom/press-releases/bauer-media-confirms-lead-as-uks-biggest-magazine-publisher-2 (accessed: 3.01.2021).

Bochyńska N., Bauer zamyka tytuty $i$ zwalnia. „Koronawirus staje się pretekstem, wymówka dla wydawców", https://www.wirtualnemedia.pl/artykul/bauer-zamyka-tytuly-i-zwalnia-koronawirus-staje-sie-pretekstem-wymowka-dla-wydawcow (accessed: 3.01.2021).

Carey J., The magazine market isn't dead, it's different, https://www.journalism.co.uk/news-commentary/the-magazine-market-isn-t-dead-it-s-different/s6/a698229/ (accessed: 3.01.2021).

Chau D., Magazine giant sells Woman's Day and New Idea for loss, despite 'significant growth' during COVID-19, https://www.abc.net.au/news/2020-06-17/bauer-media-magazine-new-idea-womans-day-covid19-coronavirus/12364510 (accessed: 3.01.2021).

Consumer ABCs: Lockdown leisure, https://mediatel.co.uk/news/2020/08/13/consumer-abcs-lockdown-leisure/ (accessed: 3.01.2021).

Consumer ABCs: Women's market, https://mediatel.co.uk/news/2020/8/13/consumer-abcs-womens-market (accessed: 3.01.2021).

Dąbrouska-Cendrouska O., Magazyny poradnikowe dla kobiet - kryzys, rozwój czy stagnacja, p. 167, https://www.researchgate.net/publication/334991776_Guidance_Magazines_for_ Woman_Crisis_Stagnation_or_Development (accessed: 3.01.2021).

Dąbrouska-Cendrouska O., Prasa kobieca w czasach ekspansji nowych mediów, „Zeszyty Prasoznaucze" 2016, Vol. 59, No. 2 (226), pp. 424-439.

Dąbrouska-Cendrouska O., Segment magazynów true story $w$ Polsce i w Wielkiej Brytanii. Analiza na podstawie „Chwili dla Ciebie” $i$ „Take a Break”, „Media i Społeczeństwo” 2020, No. 12, pp. 244-261.

Degun G., Bauer Media to close, merge or sell 10 magazines as result of COVID-19, https:// wuw.campaignlive.co.uk/article/bauer-media-close-merge-sell-10-magazines-result-COVID-19/1683592 (accessed: 3.01.2021).

Ed., Wydawcy prasy: przetrwamy w stużbie dla czytelnika tylko dzięki czytelnikowi, https:// wuw.forbes.pl/biznes/prasa-w-czasie-pandemii-koronawirusa-list-boguslawa-chraboty/ qr7rks0 (accessed: 3.01.2021).

Filas R., Polskie czasopisma w XXI wieku - rozwój czy kryzys?, „Zeszyty Prasoznawcze” 2007, No. 1-2. 
Five things you need to know from the latest PAMCo release for magazines, https://mediatel. co.uk/news/2020/09/16/five-things-you-need-to-know-from-the-latest-pamco-release-for-magazines/ (accessed: 3.01.2021).

Gough-Yates A., Understanding Women's Magazines, Taylor \& Francis Ltd, London 2002.

Gov.uk, https://uww.gov.uk/coronavirus (accessed: 3.01.2021).

Hays K., Some Magazines Suffering Amid Pandemic, Online and Off, https://wud.com/ business-news/media/some-magazines-suffering-amid-pandemic-online-and-off-1234654571/ (accessed: 3.01.2021).

Hermes J., Reading Women's Magazines, Wiley-Blackwell, Cambridge 1995.

Hopkins K., How will Coronavirus Impact Already Fragile Glossy Magazine Print Ads?, https:// wud.com/business-news/media/how-coronavirus-impact-already-fragile-magazine-print-adverti-1203558596/ (accessed: 3.01.2021).

Jefferson M., Bauer Media considers closure for ten magazines due to COVID-19, https:// mediatel.co.uk/news/2020/05/19/bauer-media-considers-closure-for-ten-magazines-due-to-COVID-19/ (accessed: 3.01.2021).

Magazine ABCs: 2019 market round-up, https://mediatel.co.uk/news/2020/02/13/magazine-abcs-2019-market-round-up/ (accessed: 3.01.2021).

Magazine ABCs: market round-up, https://mediatel.co.uk/news/2020/08/13/magazine-abcs-market-round-up-2 (accessed: 3.01.2021).

Magazines and the pandemic - how reading become more popular than ever, https://wuw.storaenso.com/en/newsroom/news/2020/6/magazines-and-the-pandemic (accessed: 3.01.2021).

Mayhew F., Pamco: Monthly mags fare better than weeklies under lockdown with some big audience gains, https://www.pressgazette.co.uk/pamco-monthly-mags-fare-better-than-weeklies-under-lockdown-with-some-big-audience-gains/ (accessed: 3.01.2021).

Nascimbene E., Magazine covers in Times of COVID-19, https://barcelonabridalueek.com/ magazine-covers-in-times-of-the-COVID-19/ (accessed: 3.01.2021).

Nrs.co.uk, http://www.nrs.co.uk/latest-results/facts-and-figures/magazines-factsfigs/ (accessed: 3.01.2021).

Nrs.co.uk, http://www.nrs.co.uk/total-market-3/ (accessed: 3.01.2021).

PAMCo: magazine readership patterns reshaped by COVID-19, https://mediatel.co.uk/ news/2020/06/17/pamco-magazine-readership-patterns-shaped-by-COVID-19/ (accessed: 3.01.2021).

Rajan A., How coronavirus infected publishing, https://wuw.bbc.com/news/entertainment-arts-52299925 (accessed: 3.01.2021).

Stawiany J., Wydawnictwo Bauer zamyka siedem tytułów i zwalnia prawie 30 osób, https:// wuw.press.pl/tresc/61447, wydawnictwo-bauer-zamyka-siedem-tytulow-i-zualnia-prawie-30-osob (accessed: 3.01.2021).

Sueney M., Between the covers: how the British fell out of love with magazines, https://www. theguardian.com/media/2019/sep/14/between-the-covers-how-the-british-fell-out-of-love-with-magazines (accessed: 3.01.2021).

Tobitt Ch., ABCs: Gardening and cooking mags biggest lockdown winners as women's titles see circulation fall, https://wuw.pressgazette.co.uk/abcs-gardening-and-cooking-mags-biggest-lockdown-winners-as-womens-titles-see-circulation-fall/ (accessed: 3.01.2021).

Tobitt Ch., Coronavirus: Time Out and Stylist free magazines go digital-only as readers stay home, https://wwu.pressgazette.co.uk/coronavirus-time-out-and-stylist-free-magazines-go-digital-only-as-readers-stay-home/ (accessed: 3.01.2021). 


\section{Weronika Sałek}

Tobitt Ch., Hearst UK prepares for COVID-19 to eat 'large proportion' of cash resources after losses of £2m in 2019, https://wuw.pressgazette.co.uk/hearst-uk-prepares-for-COVID-19-to-eat-large-proportion-of-cash-resources-after-losses-of-2m-in-2019/ (accessed: 3.01.2021).

Tobitt Ch., Women's mags ABC's: Pick Me Up and Elle circulations fall by quarter + full figures, https://wwu.pressgazette.co.uk/womens-mags-abcs-pick-me-up-and-elle-circulations-fall-by-quarter-full-figures/ (accessed: 3.01.2021).

UK Magazine SubscribtionSubscription Surge during Pandemic, https://freeportpress.com/ uk-magazine-subscriptions-surge-during-pandemic/(accessed: 3.01.2021).

WNIP, UK magazine and newspaper readership across all platforms revealed for first time, https://whatsnewinpublishing.com/uk-magazine-newspaper-readership-across-platforms-revealed-first-time/ (accessed: 3.01.2021).

Wood A., Modernism and Modernity in British Women's Magazines, Routledge, New York 2020.

Wydawcy prasy: przetrwamy w stużbie dla czytelnika tylko dzięki czytelnikowi, https://www. forbes.pl/biznes/prasa-w-czasie-pandemii-koronawirusa-list-boguslawa-chraboty/qr7rks0 (accessed: 3.01.2021).

Zinio.com, https://support.zinio.com/hc/en-us/articles/360040746832-Magazines-affected-by-COVID-19 (accessed: 3.01.2021). 